Jurnal Ekonomi dan Perbankan Syariah

Vol. 7. No.2, Agustus, 2018: 45-63, ISSN (cet): 2355-1755 | ISSN (online): 2579-6437

\title{
ANALISIS KINERJA REKSADANA SYARIAH (KATEGORI SAHAM, CAMPURAN DAN PENDAPATAN TETAP) PERIODE 2012-2017
}

\section{Dikri Rizaldi $^{1}$, Azis Budi Setiawan², Muhammad Doddy AB $^{3}$}

${ }^{1}$ Staf Pengajar Pondok Pesantren Mubarokul Ulum. Email: dikri.rizaldi@gmail.com,

${ }^{2}$ Wakil Ketua 1 Bidang Akademik Sekolah Tinggi Ekonomi Islam SEBI, Depok, Jawa Barat. Email:setiawan.aziz@gmail.com,

${ }^{3}$ Program Studi Perbankan Syariah Sekolah Tinggi Ekonomi Islam SEBI, Depok, Jawa Barat. Email:doddy.abe@gmail.com

\begin{abstract}
ABSTRAK. Tujuan penelitian ini adalah untuk mengetahui kinerja reksadana syariah kategori Saham, Campuran dan Pendapatan Tetap yang dikeluarkan oleh perusahaanperusahaan yang ada di Indonesia. Penelitian ini menggunakan metode purposive sampling yaitu dengan memilih sampel dengan kriteria tertentu. Teknik analisis dalam penelitian ini menggunakan analisis keuangan yaitu metode Sharpe. Hasil penelitian ini menunjukan bahwa : (1) Kinerja Reksadana Syariah Saham yang memiliki kinerja paling baik tahum 2012 adalah TRIM Saham Syariah, tahun 2013 adalah Cipta Equity Syariah, tahun 2014 adalah PNM Ekuitas Syariah, tahun 2015 dan tahun 2016 adalah Manulife Sektoral Syariah Amanah dan tahun 2017 adalah Batavia Dana Saham Syariah. (2) Kinerja Reksadana Syariah Campuran yang memiliki kinerja paling baik tahun 2012 dan 2013 adalah SAM Syariah Berimbang, tahun 2014 TRIM Syariah Berimbang, tahun 2015 Schorder Syariah Balance Fund, tahun 2016 AAA Amanah Syariah Fund, tahun 2017 adalah TRIM Syariah Berimbang. (3) kinerja Reksadana Syariah Pendapatan tetap yang memiliki kinerja paling baik tahun 2012, 2013 dan 2014 adalah MNC Dana Syariah Sejahtera, tahun 2015 adalah I-Hajj Syariah Fund serta tahun 2016 dan 2017 adalah MNC Dana Syariah Sejahtera.
\end{abstract}

Kata Kunci : Kinerja, Reksadana Syariah, Metode Sharpe 
46 | Dikri Rizaldi, Azis Budi Setiawan, Muhammad Doddy AB : Analisis Kinerja Reksadana

Syariah (Kategori Saham, Campuran dan Pendapatan Tetap) Periode 2012-2017

\section{PENDAHULUAN}

Indonesia merupakan negara dengan penduduknya mayoritas beragama Islam. Menururt data Badan Pusat Statistik (BPS) tahun 2010 jumlah Muslim di Indonesia mencapai 207.176.162 jiwa, dengan presentase yaitu 87,18\%. Indonesia sebagai negara muslim terbesar di dunia merupakan pasar yang sangat besar untuk pengembangan industri keuangan syariah. Industri keuangan syariah meliputi beberapa aspek diantaranya perbankan syariah, lembaga keuangan non bank syariah, asuransi syariah, serta pasar modal. Dari semua aspek tersebut hampir seluruhnya mempunyai peran dalam perkembangan Industri keuangan syariah, salah satunya adalah pasar modal.

Pasar modal merupakan pasar untuk berbagai jenis instrument keuangan jangka panjang. Peran pasar modal sangat besar dalam perekonomian karena pasar ini menjalankan dua fungsi, yaitu fungsi ekonomi dan fungsi keuangan. Fungsi ekonomi pasar modal adalah menyediakan fasilitas yang mempertemukan antara pihak yang kelebihan dana (investor) dengan pihak yang memerlukan dana (issuer). Sedangkan pasar modal dikatakan memiliki fungsi keuangan karena memberikan kemungkinan memperoleh imbal hasil bagi pemilik sesuai dengan karakteristik investasi yang dipilih. Di banyak Negara, terutama di negara- negara yang menganut sistem ekonomi pasar, pasar modal menjadi salah satu sumber kemajuan ekonomi, sebab pasar modal menjadi sumber alternatif bagi perusahaan (Widoatmodjo, 2009).

Pasar modal (Capital Market) merupakan tempat bagi berbagai pihak, khususnya perusahaan menjual saham (stock) dan obligasi (bond) dengan tujuan dari hasil penjualan tersebut nantinya akan dipergunakan sebagai tambahan dana atau untuk memperkuat modal perusahaan (Fahmi, 2012). Dengan adanya Pasar Modal maka pihak yang memiliki kelebihan dana dapat menginvestasikan dana tersebut dengan harapan dapat memperoleh imbal hasil, sedangkan pihak emiten dapat memanfaatkan dana tersebut untuk kepentingan investasi tanpa harus menunggu tersedianya dana tersebut dari operasi perusahaan.

Salah satu cara masyarakat dapat ikut serta dalam kegiatan di pasar modal adalah investasi. Investasi merupakan salah satu bentuk pemanfaatan dana yang dapat menghasilkan pendapatan bagi pemilik dana. Investasi memiliki berbagai macam bentuk, seperti deposito, obligasi, saham dan reksadana. Salah satu bentuk investasi syariah adalah reksadana syariah. Keberadaan reksadana syariah dapat mempermudah para investor untuk ikut serta dalam investasi di pasar modal tanpa harus terlibat secara langsung dalam transaksi yang dilakukan di pasar modal melalui bursa efek. Kegiatan investasi syariah di pasar modal yang merupakan bagian dari industri keuangan syariah, mempunyai peranan yang cukup penting untuk dapat meningkatkan pangsa pasar industri keuangan syariah di Indonesia.

Perkembangan reksadana syariah masih relatif baru dibandingkan dengan perbankan syariah maupun asuransi syariah, tetapi seiring dengan perkembangan yang signifikan di Industri pasar modal Indonesia, maka diharapkan investasi di Pasar Modal Indonesia akan mengalami perkembangan 
Jurnal Ekonomi dan Perbankan Syariah

Vol. 7. No.2, Agustus 2018: 45-63, ISSN (cet): 2355-1755 | ISSN (online): 2579-

6437

47

yang pesat. Reksadana Syariah merupakan sarana investasi yang menggabungkan saham dan obligasi syariah dalam satu produk yang dikelola oleh manajer investasi.(Fardiansyah, 2002).

Peranan manajer investasi sangat penting dalam reksadana syariah, Manajer bertugas menawarkan reksadana syariah kepada para Investor. Dana yang diperoleh manajer investasi dari para Investor ditanamkan dalam bentuk saham atau obligasi yang menguntungkan. Perihal reksadana ini juga telah diatur dalam Undang- Undang Nomor 9 tahun 1995 tentang Pasar Modal.

Berdasarkan mekanisme pengelolaan, reksadana dibedakan menjadi dua yaitu reksadana konvensional dan reksadana syariah. Reksadana syariah dan reksadana konvensional landasan filosofi dan metode pengelolahan yang berbeda. Perbedaan pokok tentang reksadana konvensional dengan reksadana syariah terdapat pada screening process sebagai bagian dari proses alokasi aset. Reksadana syariah hanya boleh melakukan penempatan pada sahamsaham dan instrumen lain sesuai dengan syariat Islam. Perbedaan reksadana syariah ini berdampak pada alokasi dan komposisi aset dalam portofolionya. Reksadana syariah melakukan cleansing procces yang bermaksud membersihkan dari pendapatan yang tidak halal dan tidak sesuai Syariat Islam (Huda \& Nasution, 2014).

Perkembangan reksadana syariah tidak terlepas dari berbagai macam faktor yang mempengaruhinya. Perubahan yang terjadi pada faktor-faktor tersebut dapat mempengaruhi perkembangan reksadana syariah baik secara positif maupun negatif. Pengelolaan reksadana syariah terhadap manajemen investasinya yaitu dengan cara mengelola dana-dana yang ditempatkan pada surat berharga dan merealisasikan keuntungan ataupun kerugian dan menerima deviden atau bunga yang dibukukannya ke dalam "Nilai Aktiva Bersih" (NAB) reksadana tersebut

Manfaat yang dapat diperoleh investor jika melakukan investasi pada produk reksadana ialah, walaupun dengan modal terbatas, investor tetap dapat melakukan diversifikasi dalam investasi efek, sehingga mampu memperkecil risiko. Melalui reksadana inilah, maka akan terkumpul dana dalam jumlah yang besar sehingga memudahkan diversifikasi portofolio investasi. Sebagian besar investor hanya memiliki pengetahuan dan keahlian yang terbatas untuk menentukan saham, obligasi, dan instrument keuangan lainnya, yang sekiranya baik untuk dibeli. Dengan melakukan investasi pada reksadana yang dikelola oleh manajer investasi profesional, maka hal tersebut bukan lagi menjadi hambatan bagi investor untuk bisa berinvestasi di pasar modal.

Sama halnya dengan alternatif instrumen keuangan lainnya, reksadana juga mengandung berbagai kemungkinan terjadinya risiko disamping mendatangkan berbagai peluang keuntungan. Beberapa risiko yang dikandung reksadana antara lain : (1) risiko berkurangnya aktiva bersih, yang dipengaruhi oleh turunnya harga dari efek yang masuk dalam portofolio reksadana tersebut; (2) risiko likuiditas, manajer investasi akan mengalami kesulitan dalam menyediakan uang tunai apabila sebagian besar pemegang unit penyertaan 
48 | Dikri Rizaldi, Azis Budi Setiawan, Muhammad Doddy AB : Analisis Kinerja Reksadana Syariah (Kategori Saham, Campuran dan Pendapatan Tetap) Periode 2012-2017

yang dipegangnya; (3) risiko gagal bayar, risiko ini muncul ketika perusahaan asuransi yang mengasuransikan kekayaan reksadana tidak segera membayar ganti rugi atau membayar lebih rendah dari nilai pertanggungan saat terjadi hal-hal yang tidak diinginkan.

\section{LANDASAN TEORI}

\section{Investasi, Teori Reksadana, Kinerja Reksa Dana}

Menururt PSAK nomor 13 dalam Standar Akuntansi Keuangan per 1 Oktober 2014 invesatasi adalah aset yang digunakan perusahaan untuk pertumbuhan kekayaan ( accretion of wealth) melalui distribusi hasil investasi (seperti bunga, royalty, deviden dan uang sewa) untuk apresiasi nilai investasi atau manfaat lain bagi perusahaan yang berinvestasi seperti manfaat yang diperoleh melalui hubungan perdagangan.

Secara umum investasi atau penanaman modal dapat diartikan sebagai suatu kegiatan yang dilakukan baik oleh orang pribadi (natural person) maupun badan hukum (judicial person) dalam upaya untuk meningkatkan dana untuk memperthanakan nilai modalnya baik berbentuk uang tunai, peralatan, aset tidak bergerak, hak atas kekayaan intelektual maupun keahlian (Rohmatusya'diyah, 2011).

Investasi memeiliki pengertian yang lebih luas karena dapat mencakup baik investasi langsung (direct investment) maupun investasi tidak langsung (portopolio investment), sedangkan penanaman modal lebih memiliki konotasi kepada investasi langsung.

Investasi langsung (direct investment) adalah mereka yang memiliki dana dapat berinvestasi dengan membeli secara langsung suatu aktiva keuangan dari suatu perusahaan yang dapat dilakukan melalui perantara atau berbagai cara lainnya. Sedangkan investasi tidak langsung (portopolio investment) adalah mereka yang memiliki kelebihan dana dapat melakukan keputusan investasi dengan tidak terlibat secara langsung atau pembelian aktiva keuangan cukup hanya dengan memegang bentuk saham atau obligasi saja (Jogiyanto:2008).

Pada dua bentuk investasi tersebut Wiliam F Sharpe dkk. Menegaskan bahwa pada perekonomian primitif hampir semua investasi lebih ke investasi nyata, sedangkan pada perekonomian modern lebih banyak dilakukan investasi keuangan. Jadi kedua bentuk investasi tersebut bersifat komplementer bukan kompetitif. Dengan demikian kemajuan ekonomi suatu negara dapat dilihat dari keberedaan dan kualitas bursa efeknya yang diakui oleh para pebisnis (fahmi I. , 2012).

Islam mendororng setiap manusia untuk bekerja dan meraih sebanyakbanyak materi. Islam memperbolehkan setiap manusia mengusahakan harta sebanyak yang ia mampu, mengembangkan, memanfaatkannya sepanjang tidak melanggar ketentuan agama.

Dalam Islam investasi merupakan kegiatan muamalah yang sangat dianjurkan, karena dengan berinvestasi, harta yang dimiliki menjadi produktif 
Jurnal Ekonomi dan Perbankan Syariah

Vol. 7. No.2, Agustus 2018: 45-63, ISSN (cet): 2355-1755 | ISSN (online): 25796437

49

dan mendatangkan manfaat bagi orang lain. Al- Quran dengan tegas melarang aktivitas penimbunan terhadap harta yang dimiliki. Dalam sebuah hadits, Nabi Muhammad SAW bersabda :" Ketahuilah, barang siapa yang memelihara anak yatim, sedangkan anak yatim tersebut memiliki harta, maka hendaklah ia menginvestasikan, janganlah ia membiarkan harta itu idle, sehingga harta itu berkurang lantaran zakat (Yuliana, 2010).

Investasi merupakan salah satu ajaran dari konsep islam. Hal tersebut dapat dibuktikan bahwa konsep investasi selain sebagai pengetahuan juga bernuanasa spritiual karena menggunakan prinsip syariah, sekaligus merupakan sebuah hakikat dari sebuah ilmu dan amal, oleh karenanya investasi sangat dianjurkan bagi setiap muslim. (Huda \& Nasution, 2014).

Dalam investasi Allah dan Rasul-Nya memberikan petunjuk (dalil) dan rambu- rambu pokok yang dapat diikuti oleh setiap umat muslim yang beriman. Di antara rambu- rambu tersebut adalah sebagai berikut :

a. Terbebas dari unsur riba

Riba secara etimologi berarti tumbuh dan bertambah. Riba dilarang karena termasuk dalam kategori mengambil atau memperoleh harta dengan cara tidak benar.

b. Terhindar dari unsur gharar

Gharar secara etimologi bermakna kekhawatiran atau risiko, dan gharar juga berarti menghadapi suatu kecelakaan, kerugian dan kebinasaan.

c. Terhindar dari unsur judi (maysir)

Maysir merupakan bentuk objek yang diartikan sebagai tempat untuk memudahkan sesuatu. Dikatakan memudahkan sesuatu karena seseorang yang seharusnya menempuh jalan yang susah payah akan tetapi mencari jalan pintas dengan harapan mendapatkan apa yang dikehendaki, walaupun jalan pintas tersebut bertentangan dengan nilai serta aturan syariah.

d. Terhindar dari unsur haram

Investasi yang dilakukan oleh investor muslim diharuskan terhindar dari unsur haram. Sesuatu yang haram merupakan segala sesuatu yang dilarang oleh Allah SWT dan Rasul-Nya.

\section{e. Terhindar dari unsur syubhat}

Kata syubhat berarti serupa, mirip, semisal dan bercampur. Dalam terminologi syariah syubhat berarti sebagai sesuatu perkara yang tercampur (antara halal dan haram), akan tetapi tidak diketahui secara pasti apakah ia sesuatu yang halal atau haram, apakah ia hak ataukah batil. Seoramg investor muslim disarankan menjauhi aktivitas investasi yang beraroma syubhat, karena jika hal tersebut tetap dilakukan maka pada hakikatnya telah terjerumus pada sesuatu yang haram. (Huda, 2007). 
50 | Dikri Rizaldi, Azis Budi Setiawan, Muhammad Doddy AB : Analisis Kinerja Reksadana Syariah (Kategori Saham, Campuran dan Pendapatan Tetap) Periode 2012-2017

\section{Teori Reksadana}

Reksadana merupakan kumpulan saham, obligasi, atau sekuritas jenis lain yang dibeli oleh sekelompok investor dan dikelola oleh perusahaan investasi professional (Jacobs, Bruce, 1994). Reksadana syariah secara etimologi berasal dari kata " Reksa" yang artinya polis atau penjaga, sedangkan kata "Dana" artinya uang yang disediakan untuk keperluan. Sehingga dapat diartikan sebagai uang yang dijaga atau sekumpulan uang yang dipelihara bersama untuk keperluan bersama (Darmadji, 2001).

Sedangkan reksadana syariah mengandung pengertian sebagai reksa dana yang pengelolaan dan kebijakan investasinya mengacu pada Syariat Islam (Sudarsono, 2007). Reksadana merupakan salah satu alternatif investasi yang dirancang sebagai sarana untuk menghimpun dana dari masyarakat yang memiliki modal dan keinginan melakukan investasi, namun hanya memiliki waktu, pengetahuan serta keahlian menghitung risiko investasi yang memiliki modal dan keinginan melakukan investasi, namun hanya memiliki waktu, pengetahuan serta keahlian menghitung risiko investasi yang terbatas. Undang-undang Pasar Modal Nomor 8 Tahun 1995, pasal 1 ayat 27 mendefinisikan reksadana sebagai wadah yang dipergunakan untuk menghimpun dana dari masyarakat investor, untuk selanjutnya diinvestasikan dalam portofolio efek oleh manajer investasi.

Dari pengertian reksadana tersebut, terdapat tiga hal yang terkait dari definisi tersebut (Manurung, 2003), yaitu :

a. Adanya dana dari masyarakat investor

Investor dari reksadana dapat perseorangan ataupun lembaga dimana masing-masing pihak memiliki tujuan investasi yang berbeda-beda. Tujuan investasi para investor secara garis besar dapat dikelompokan ke dalam tiga hal, yaitu untuk alasan keamanan (berjaga-jaga) untuk mendapatkan pendapatan konstan, dan untuk mengejar nilai pertumbuhan nilai dana.

Secara umum dapat dikatakan bahwa investasi awal minimum untuk membeli reksadana adalah berkisar antara Rp. 250.000 sampai Rp. 10.000.000. Ada pula beberapa reksadana yang menetapkan persyaratan investasi minimum $\mathrm{Rp}$. 100.000 .

b. Dana tersebut diinvestasikan dalam portofolio efek

Dana yang dikumpulkan dari masyarakat diinvestasikan ke dalam instrument investasi atau efek seperti deposito, obligasi, saham, dan sebagainya. Manajer Investasi membentuk portofolio dengan melakukan alokasi aset yang berbeda-beda pada berbagai instrumen investasi sesuai dengan perhitungan Manajer Investasi untuk mencapai tujuan investasi, yaitu tingkat pengembalian yang diharapkan.

c. Dana tersebut dikelola oleh Manajer Investasi

Pengelolaan reksadana dilakukan oleh perusahaan yang telah mendapatkan izin dari OJK yang menggantikan peran BAPEPAM sebagai manajer investasi. Perusahaan pengelola reksadana ini dikenal sebagai perusahaan efek atau perusahaan investasi. Selain perusahaan manajemen investasi yang bergerak sebagai pengelola dana, pihak lain yang terlibat dalam pengelolaan suatu reksadana adalah bank kustodian. Bank Kustodian memiliki 
Jurnal Ekonomi dan Perbankan Syariah

Vol. 7. No.2, Agustus 2018: 45-63, ISSN (cet): 2355-1755 | ISSN (online): 2579-

6437

| 51

wewenang dan tanggung jawab dalam hal menyimpan, menjaga, dan mengadministrasikan kekayaan, baik dalam pencatatan maupun pembayaran atau penjualan kembali suatu reksadana berdasarkan kontrak yang dibuat bersama oleh manajer investasi. Dalam Undang-undang pasar modal disebutkan bahwa kekayaan reksadana wajib disimpan pada bank kustodian sehingga pihak manajer investasi tidak memegang langsung kekayaan tersebut. Selain itu, bank kustodian dilarang berafiliasi dengan manajer investasi untuk menghindari adanya benturan kepentingan dalam pengelolaan kekayaan reksadana.

Jika dilihat berdasarkan portofolio investasinya, maka reksadana dapat dibedakan menjadi :

\section{a. Reksadana Pasar Uang}

Reksadana jenis ini menekankan pada upaya menjaga likuiditas dan pemeliharaan modal dengan membentuk portofolio yang teridiversifikasi pada berbagai instrument jangka pendek (kurang dari satu tahun), seperti Serifikat Bank Indonesia (SBI), Surat Berharga Pasar Uang (SBPU), Commercial Paper, Promissory Notes, Call Money, Banker Acceptance, Repurchase Agreement, dan lain-lain.

Reksadana pasar uang merupakan reksadana dengan tingkat risiko paling rendah, tetapi potensi keuntungannya terbatas. Dengan risiko paling rendah ini sangat cocok untuk investor pemula atau yang tidak berani mengambil risiko tinggi dan juga bagi mereka yang mempunyai tujuan untuk investasi jangka pendek (Cahyono, 2001), sebagai pelengkap investasi deposito atau tabungan yang sudah ada. Jenis reksadana yang cocok untuk tujuan investasi jangka pendek, dengan mengutamakan proteksi nilai investasi awal namun tetap memberikan tingkat pengembalian yang menarik (safety fund). Dikatakan demikian karena hampir $100 \%$ dananya diinvestasikan pada pasar uang (Huda \& Nasution, 2014).

Tujuan investasi reksadana pasar uang adalah untuk perlindungan modal dan untuk menyediakan tingkat likuidutas tinggi, sehingga jika dibutuhkan, investor dapat mencairkan setiap hari kerja dengan risiko penurunan nilai investasi yang hampir tidak ada. Dalam reksadana pasar uang kemungkinan hasil negatif ada, namun sangat kecil. Tidak seperti saham dan obligasi yang berjangka pendek umumnya memiliki harga yang tetap (Priyo, 2002)

b. Reksadana Pendapatan Tetap

Reksadana Pendapatan tetap adalah reksadana yang melakukan investasi sekurang- kurangnya $80 \%$ dari portofolio yang dikelolanya ke dalam efek berisfat utang (Darmadji \& Fachrudin, Pasar Modal di Indonesia Pendekatan Tanya Jawab, 2008). Pengalokasian aset pada reksadana pendapatan tetap dikonsentrasikan pada berbagai tipe obligasi yang dikelompokan menjadi obligasi pemerintah, obligasi korporasi, dan obligasi pemerintah daerah (municipal bond) yang dapat menggeneralisasi adanya tingkat pengembalian yang stabil dengan tingkat kemungkinan risiko yang 
lebih tinggi dari reksadana pasar uang, namun lebih rendah dibanding dengan kemungkinan risiko pada reksadana saham.

Efek bersifat utang umumnya memberikan penghasilan dalam bentuk bunga seperti Deposito, Obligasi, SBI dan instrumen lainnya. Untuk mencapai tujuan tersebut, komposisi investasi reksadana ini difokuskan pada sarana investasi yang menwarkan hasil pasti seperti surat utang (Obligasi) dan instrumen pasar uang.

c. Reksadana saham

Reksadna jenis ini mengalokasikan lebih dari $80 \%$ dananya pada efek yang bersifat ekuitas (saham) (Priyo \& Nugraha, Reksa Dana solusi investasi perencanaan investasi di era modern, 2002), terutama saham biasa (common stock), Saham dikenal dengan karakteristik "imbal hasil tinggi, risiko tinggi". Artinya, reksadana saham merupakan surat berharga yang memberikan peluang keuntungan yang tinggi, namun memberikan potensi risiko yang tinggi pula.

Efek pendapatan tetap seperti deposito dan obligasi yang orientasinya pada pendapatan dan bagi hasil berbeda dengan efek saham, dimana efek saham umumnya memberikan potensi hasil yang lebih tinggi berupa capital gain melalui pertumbuhan harga- harga saham. Selain capital gain, efek saham memberikan hasil lain berupa dividen. Reksadana ini investasinya menawarakan potensi pertumbuhan yang paling besar.

d. Reksadana Campuran

Reksadana ini menanamkan dananya pada berbagai macam instrument investasi, baik pasar uang, obligasi atau saham dengan komposisi yang beragam. Komposisi investasi ini harus tercantum dalam perencanaan investasi prospektus. Misalnya bauran AAA Amanah Syariah Fund menanamkan dananya untuk deposito $13.1 \%, 21,9 \%$ untuk obligasi syariah dan sisanya yang 60\% untuk saham (Prayitno \& Pangalila, 2008).

Reksadana campuran melakukan investasi dalam efek ekuitas dan hutang yang perbandingannya (alokasi) tidak termasuk dalam kategori pendapatan tetap dan dan reksadana saham. Reksdana ini mempunyai kelebihan dalam fleksibilitasnya, baik dalam pemilihan jenis investasi (saham, obliagasi, deposito atau efek lainnya) serta komposisi alokasinya, reksadana campuran dapat berorientasi ke saham, obliagasi, atau ke pasar uang. Fleksibilitas ini digunakan untuk berpindah- pindah dari saham ke obligasi atau deposito tergantung dari keadaan pasar atau situasi saat ini. Dan sebaliknya tergantung pada kondisi pasar dengan melakukan aktifitas trading, yang merupakan usaha untuk meningkatkan investasi dana atau menurunkan risiko (Ghazali, 2004).

Salah satu poin yang harus diperhatikan investor sebelum memilih berinvestasi pada reksa dana adalah melakukan penilaian terhadap kinerja reksa dana yang ingin dimiliki. Pengukuran kinerja reksa dana dikenal dengan istilah Evaluation of Porotofolio Performance. Evaluasi terhadap kinerja yang menerangkan bahwa metode evaluasi kinerja secara khusus hanya mengukur risk and return berdasarkan portofolio investasi. Beberapa metode yang pada 
Jurnal Ekonomi dan Perbankan Syariah

Vol. 7. No.2, Agustus 2018: 45-63, ISSN (cet): 2355-1755 | ISSN (online): 2579-

6437

| 53

umumnya digunakan adalah Risk Adjusted Return, Sharpe Ratio, Treynor Ratio dan Capital Asset Pricing Model (Rudiyanto, 2015).

Untuk mengetahui jenis investasi yang dimiliki investor apakah telah mencapai sasaran atau tidak adalah perlu dengan cara menghitung dan mengukur kinerja kinerja portofolio setiap saat. Kinerja portofolio dapat dihitung berdasarkan return portofolio saja. Akan tetapi karena adanya tukaran (trade-off) antara return dan risiko, maka pengukuran portofolio berdasarkan return saja mungkin tidak cukup. Oleh sebab itu, harus mempertimbangkan kedua hal tersebut yaitu return dan risikonya. Pengukuran yang melibatkan kedua faktor ini disebut dengan imbal hasil sesuai risiko (risk adjusted return) (Hartono, 2013).

Nilai Aktiva Bersih atau disebut Net Asset Value (NAV) ialah nilai pasar wajar (fair market value) suatu efek dan kekayaan lain dari reksa dana yang telah dikurangi dengan kewajiban. Sedangkan NAB per unit penyertaan adalah harga wajar dari portofolio suatu reksa dana setelah dikurangi biaya operasional dibagi kumlah unit penyertaan yang telah beredar pada saat tersebut (Suketi \& Wahyudi, 2011).

Perhitungan NAB berguna untuk mengetahui berapa nilai aset investasi dari reksa dana tersebut sehingga dapat diketahui berapa perkembangan aset investasi sampai pada periode tertentu (Nurjannah, 2015).

Menurut Jogiyanto (2007) dalam Susilatri, Ratnawati \& Khairani (2014) return merupakan hasil yang diperoleh dari kegiatan investasi. Return Reksa dana adalah perubahan nilai reksa dana ditambah income beberapa dividen ataupun bunga yang terjadi selama periode kinerja. Return reksa dana merupakan cerminan dari kinerja suatu jenis reksa dana. Indikator umum yang dipakai oleh investor maupun manajer investasi dalam menilai kinerja berbagai jenis reksa dana ialah nilai aktiva bersih. Perhitungan imbal hasil portofolio dapat dihitung dengan cara yang sama dengan yang dilakukan untuk menghitung return aktiva tunggal.

Return pasar merupakan imbal hasil pasar dimana instrumen investasi atau reksa dana beredar atau diperdagangkan. Salah satu indeks yang dipakai di BEI dan menjadi parameter penting untuk keadaan pasar modal Indonesia adalah IHSG. Parameter lainnya adalah LQ45 yang memuat 45 saham terpilih dengan likuiditas dan kapitalisasi saham yang tinggi, Jakarta Islamic Index (JII) memuat saham- saham yang sesuai prinsip syariah (Susilatri, Ratnawati, \& Khairani, 2014).

Investasi tanpa risiko diasumsikan merupakan tingkat suku bunga ratarata dari Sertifikat Bank Indonesia (Pratomo, 2005). Apabila nilai Sertifikat Bank Indonesia (SBI) tidak konstan dalam beberapa periode dan pengukuran digunakan untuk mengukur kinerja portofolio yang sudah terjadi, maka digunakan nilai rata-rata dari nilai historisnya. Selain itu, apabila data SBI adalah data bulanan maka imbal hasil bebas risiko tahunan dibagi dua belas (Hartono, 2013). 
54 | Dikri Rizaldi, Azis Budi Setiawan, Muhammad Doddy AB : Analisis Kinerja Reksadana Syariah (Kategori Saham, Campuran dan Pendapatan Tetap) Periode 2012-2017

Kinerja historis reksa dana menjadi pertimbangan utama dari investor dalam memilih reksa dana, maka dari itu perlunya standarisasi pengukuran kinerja sehingga kinerja suatu reksa dana dapat diabndingkan dengan lainnya (Pratomo, 2005).

Beberapa metode pengukuran kinerja reksa dana antara lain sebagai berikut :

\section{a. Return Portofolio}

Perhitungan return portofolio dapat dihitung dengan cara yang sama dengan yang dilakukan untuk menghitung return aktiva tunggal. Perhitungan imbal hasil di atas hanya melibatkan satu periode saja, yaitu antara waktu membeli portofolionya sampai waktu menjual portofolionya. Jika investasi portofolio melibatkan beberapa periode, maka perhitungan return rata- rata dapat dilakukan dengan cara rata- rata geometric dan rata- rata timbangan rupiah.

\section{b. Imbal Hasil Sesuaian Risiko}

Return yang tinggi saja belum tentu merupakan hasil investasi yang baik. Return yang rendah juga dapat merupakan hasil investasi yang baik jika return yang rendah ini disebabkan oleh risiko yang rendah pula. Oleh sebab itu return yang dihitung perlu disesuaikan dengan risiko yang harus ditanggungnya. (Hartono, 2013).

\section{METODOLOGI PENELITIAN}

Data yang digunakan dalam penelitian ini merupakan data sekunder. Data Sekunder adalah data yang diperoleh dalam bentuk jadi dan telah diolah oleh pihak lain dalam bentuk publikasi (Supranto, 2000). Jadi data sekunder adalah data yang telah diterbitkan atau digunakan oleh pihak lain (Suharyadi \& Purwanto, 2007).

Data yang dikumpulkan untuk penelitian ini terdiri dari :

a. Data Nilai Aktiva Bersih (NAB) dari Reksadana Saham, Reksadana Campuran, dan Reksadana Pendapatan tetap yang diperoleh dari website Otoritas jasa Keuangan (OJK) yaitu ojk.go.id dan kontan.co.id periode 2012 sampai 2017.

b. Data tentang perkembangan Benchmark yang diperoleh dari Google Finance

c. Tingkat suku bunga Serifikat Bank Indonesia (SBI) yang diperoleh dari website Bank Indonesia yaitu www.bi.go.id serta artikel-artikel yang relevan dengan penelitian. Data yang digunakan dalam penelitian ini bersifat time series,yaitu data yang diamati selama periode tertentu terhadap objek penelitian.

Populasi yang digunakan dalam Reksadana ini adalah Reksadana saham syariah, Reksadana Campuran dan Reksadana Pendapatan Tetap yang terdaftar di OJK dari tahun 2012 sampai tahun 2017. Dari tahun 2012 dan 2013 terdapat 13 Reksadana Saham, 8 Reksadana Pendapatan Tetap dan 16 Reksadana Campuran. Sedangkan Tahun 2014 tedapat 20 Reksadana Saham, 18 Reksadana Campuran serta 8 Reksadana Pendapatan tetap. Pada tahun 2015 terdapat 15 Reksadana Saham, 18 Reksadana Campuran serta 12 Reksadana Pendapatan tetap. Sedangkan pada tahun 2016 terdapat 27 Reksadana Saham, 20 Reksadana Campuran serta 19 Reksadana Pendapatan tetap. Pada 2017 
Jurnal Ekonomi dan Perbankan Syariah

Vol. 7. No.2, Agustus 2018: 45-63, ISSN (cet): 2355-1755 | ISSN (online): 25796437

$\mathbf{5 5}$

terdapat 36 Reksadana Saham, 24 Reksadana Campuran, serta 26 Reksadana Pendapatan tetap.

Sampel adalah sebagian atau wakil populasi yang diteliti. Penelitian yang dilakukan hanya menggunakan sebagian atau wakil dari populasi (Trianto, 2010). Pengambilan sampel ini menggunakan purposive sampling yaitu dengan memilih sampel dengan kriteria tertentu. Kriteria yang digunakan dalam pengambilan sampel yaitu :

a. Reksadana Syariah yang masih aktif pada periode 2012 sampai 2017 dan tercatat di OJK

b. Reksadana merupakan jenis reksadana saham, Campuran, dan pendapatan tetap

c. Sampel yang diambil merupakan produk dari perusahaan reksadana syariah yang aktif selama tahun 2012 sampai dengan 2017 dan memiliki Nilai Aktiva Bersih (NAB) yang dipublikasikan di media.

Dalam penelitian ini menggunakan analisis kuantitaif dari data yang tersedia, penelitian reksadana syariah kategori saham, csmpuran dan pendapatan tetap ini menggunakan metode Sharpe. Untuk mencapai tujuan dalam melakukan penelitian ini maka metode analysis yang digunakan melalui beberapa tahap yaitu:

\section{a. Analisis penilaian kinerja Reksadana dengan metode Sharpe}

Menurut (Hartono, 2013) Rate of Return merupakan tingkat pengembalian saham atas investasi yang dilakukan oleh investor untuk menentukan NAB unit mingguan diperoleh dari NAB unit harian yang telah diterbitkan secara online. Jika investor melakukan transaksi jual beli pada hari ini harga yang akan didapatkan baru akan diketahui pada keesokan harinya sehingga publikasi tersebut dapat memberikan indikasi kepada investor untuk melakukan keputusan jual beli. Langkah- langkah analisisnya dapat diketahui dengan rumus :

a. Menentukan return masing-masing reksadana

$$
\mathrm{R}_{\mathrm{p}}=\frac{\mathrm{NAB} t^{-N A B} \mathrm{t}-1}{\mathrm{NAB} \mathrm{t}-1}
$$

b. Menentukan standar deviasi return reksadana

$$
\mathrm{S}=\frac{\sqrt{\sum(X-x)^{2}}}{n-1}
$$

c. Menentukan investasi return bebas risiko

$$
\mathrm{R}_{\mathrm{RF}}=\frac{\sum S B I}{\sum P E R I O D E}
$$

d. Menetukan kinerja dengan metode sharpe

$$
\mathrm{S}_{\mathrm{RD}}=\frac{\text { KINERJA } R D-\text { KINERJA } R F}{\sigma}
$$


56 | Dikri Rizaldi, Azis Budi Setiawan, Muhammad Doddy AB : Analisis Kinerja Reksadana Syariah (Kategori Saham, Campuran dan Pendapatan Tetap) Periode 2012-2017

\section{ANALISIS DAN PEMBAHASAN}

Seiring dengan diberlakukannya Undang- undang No. 8 tahun 1995 tentang Pasar Modal, Reksadana mulai dikenal oleh masyarakat sejak diterbitkannya Reksadana berbentuk perseroan pada tahun 1995 yang dikeluarkan oleh PT. BDNI Reksa dana. Reksa dana ini bersifat tertutup dimana setelah melakukan penawaran umum, transaksi jual-beli saham reksa dana tersebut melalui bursa layaknya perusahaan public lainnya. Berdirinya reksa dana ini merupakan cikal bakal semaraknya pertumbuhan reksa dana di Indonesia.

Pada awal tahun 1996, Bapepam mengeluarkan peraturan pelaksanaan tentang reksa dana berbentuk Kontrak Investasi Kolektif (KIK). Pada saat itu sampai pertengaham tahun 1997, industri ini mekar dari hanyai 1 izin penerbitan menjadi 24 dengan total aset $\mathrm{Rp}$. 2,78 triliun dan kemudian mencapai puncaknya pada bulan Juli 1997 dan jumlah reksa dana 76 dengan total aset Rp. 8,3 triliun. (Hamid, 2009).

Sayangnya, krisis ekonomi tahun 1997 berimbas pada perkembangan selanjutnya. Krisis ini mulanya berasal dari permasalahan mata uang hingga menyebar ke aspek- aspek lainnya termasuk Pasar Modal. Reksa dana pun ikut terkena imbasnya. Bahkan ada beberapa Manajer Investasi yang terpaksa harus menutup reksa dana karena kondisi perekonomian yang terus memburuk (Samsul, 2015).

Namun, membaiknya pasar telah membangkitkan kembali optimisme pada pelaku pasar. Data bulan Januari hingga pertengahan tahun 2000 menunjukan bahwa pertumbuhan aset reksa dana yang konsisten dan mampu menghimpun kembali dana masyarakat yang lebih dari Rp. 5,4 triliun dan juga jumlah pemodal yang memasuki industri ini terus membengkak.

Industri reksa dana tahun 2004- 2005 mengalami bearish industri, ini dipicu oleh jatuhnya harga obligasi, reksa dana pendapatan tetap yang berbasis obligasi ikut terpukul. Pada saat itu, hampir $70 \%$ total aset reksa dana adalah kontribusi dari sumbangan reksa dana pendapatan tetap. Ini disebabkan oleh misleading informasi dari pemasar reksa dana, terutama yang ada di sektor perbankan bahwa reksa dana pendapatan tetap adalah reksa dana tanpa risiko dan return-nya lebih besar dari deposito.

\section{a. Deskripsi Kinerja Reksadana Syariah Saham}

Penelitian ini bertujuan untuk menjelaskan kinerja reksadana syariah saham terhadap retutn dari Sertifikat Bank Indonesia. Penelitian ini menggunakan periode penelitian Januari 2012 sampai dengan Desember 2017 dengan menggunakan data NAB harian.

Data yang digunakan menggunakan NAB pada awal dan akhir periode perhitungan. Rumus yang digunakan adalah sebagai berikut :

$\mathrm{R}_{\mathrm{RD}}=\frac{N \mathrm{NB}_{T}-\mathrm{NABT}_{\mathrm{t}-1}}{\mathrm{NABT}_{\mathrm{t}-1}}$

Keterangan :

$\mathrm{R}_{\mathrm{RD}}$

$=$ Return Reksadana 
Jurnal Ekonomi dan Perbankan Syariah

Vol. 7. No.2, Agustus 2018: 45-63, ISSN (cet): 2355-1755 | ISSN (online): 2579-

6437

57

$\mathrm{NAB}_{\mathrm{t}} \quad=$ Return Reksadana saat ini

$\mathrm{NAB}_{\mathrm{t}-1} \quad=$ Return Reksadana periode sebelumnya

Grafik 1 Daily Return Reksadana Saham Syariah

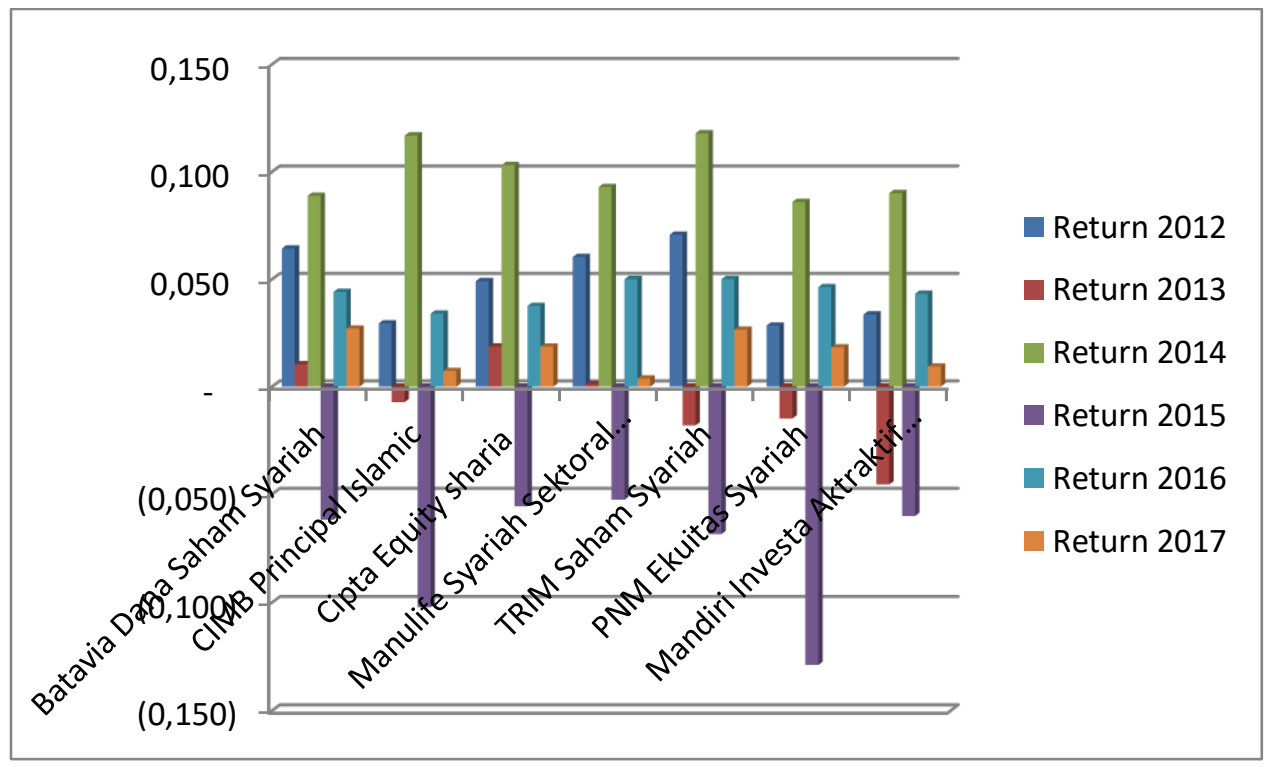

Sumber : Data Sekunder yang diolah peneliti

Dari grafik di atas terlihat bahwa dalam rentang waktu periode 2012 2017 daily return reksadana saham syariah mengalami fluktuasi. Pada periode 2012 seluruh reksadana saham syariah mencatatkan daily return yang positif, TRIM Saham Syariah mencatatkan daily return tertinggi dibanding reksadana saham syariah lainnya. Pada periode 2013 ada 4 reksadana saham syariah yang mencatatkan daily return negatif yaitu CIMB Principal Islamic, TRIM Saham Syariah, PNM Ekuitas Syariah dan Mandiri Investa Atraktif Syariah.

Pada periode 2014 seluruh reksadana saham syariah mencatatkan daily return yang positif, TRIM Saham Syariah mencatatkan daily return teringgi disbanding reksadana saham syariah lainnya. Pada periode 2015 seluruh reksadana saham syariah mencatatkan daily return yang negatif. Pada periode 2016 seluruh reksadana saham syariah mencatatkan daily return positif, Manulife Syariah Sektoral Amanah mencatatkan daily return tertinggi dibanding reksadana saham syariah lainnya. Pada periode 2017 seluruh reksadana saham syariah mencatatkan daily return positif, Batavia Dana Saham Syariah mencatatkan daily return tertinggi dibanding reksadana saham syariah lainnya. 
58 | Dikri Rizaldi, Azis Budi Setiawan, Muhammad Doddy AB : Analisis Kinerja Reksadana Syariah (Kategori Saham, Campuran dan Pendapatan Tetap) Periode 2012-2017

\section{b. Deskripsi Kinerja Reksadana Syariah Campuran}

Kinerja ke- 9 Reksadana Syariah Campuran berdasarkan rata- rata pertumbuhan harian

\section{Grafik 2 Daily Return Reksadana Campuran Syariah}

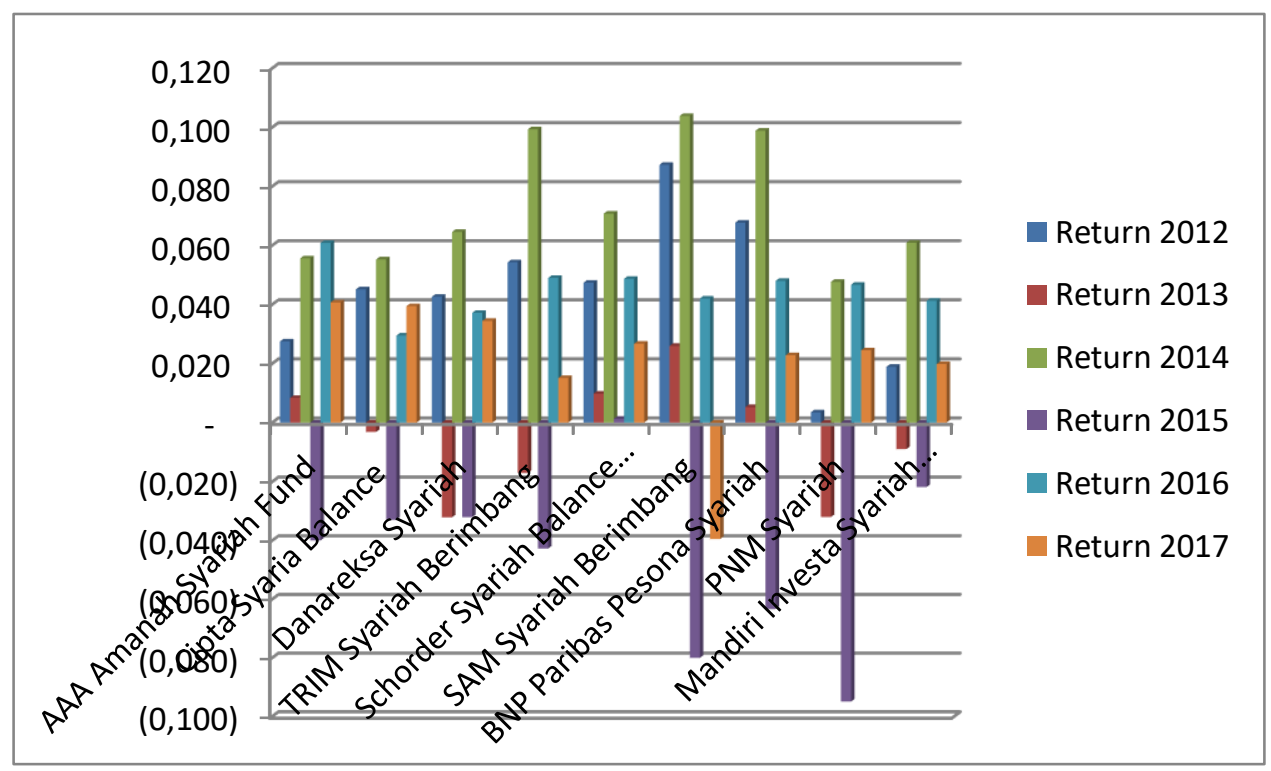

Sumber : Data Sekunder yang diolah peneliti

Dari grafik di atas terlihat bahwa dalam rentang waktu periode 2012 2017 daily return reksadana saham syariah mengalami fluktuasi. Pada periode 2012 seluruh reksadana campuran syariah mencatatkan daily return yang positif, SAM Syariah Berimbang mencatatkan daily return tertinggi dibanding reksadana campuran syariah lainnya. Pada periode 2013 ada 4 reksadana campuran syariah yang mencatatkan daily return negatif yaitu Cipta Syariah Balance, Danareksa Syariah, TRIM Syariah Berimbang, dan PNM Syariah. Pada periode 2014 seluruh reksadana campuran syariah mencatatkan daily return positif, SAM Syariah Berimbang mencatatkan daily return tertinggi dibanding reksadana campuran syariah lainnya.

Pada periode 2015 ada 8 dari 9 reksadana campuran syariah yang mencatatkan daily return negatif. Hanya Schorder Syariah Balance Fund yang mencatatkan daily return positif. Pada periode 2016 seluruh reksadana campuran syariah mencatatkan daily return positif, AAA Amanah Syariah Fund mencatatkan daily return tertinggi dibanding reksadana campuran 
Jurnal Ekonomi dan Perbankan Syariah

Vol. 7. No.2, Agustus 2018: 45-63, ISSN (cet): 2355-1755 | ISSN (online): 25796437

\section{| 59}

syariah lainnya. Pada periode 2017 ada 8 dari 9 reksadana campuran syariah yang mencatatkan daily return positif. SAM Syariah Berimbang menjadi satusatunya reksadana yang mencatatkan daily return negatif. AAA Amanah Syariah Fund mencatatkan daily return tertinggi dibanding reksadana campuran syariah lainnya.

\section{c. Deskripsi kinerja Reksa dana Syariah Pendapatan Tetap}

Kinerja ke- 7 Reksadana Syariah Pendapatan Tetap berdasarkan ratarata pertumbuhan harian

\section{Grafik 3 Daily Return Reksadana Pendapatan Tetap Syariah}

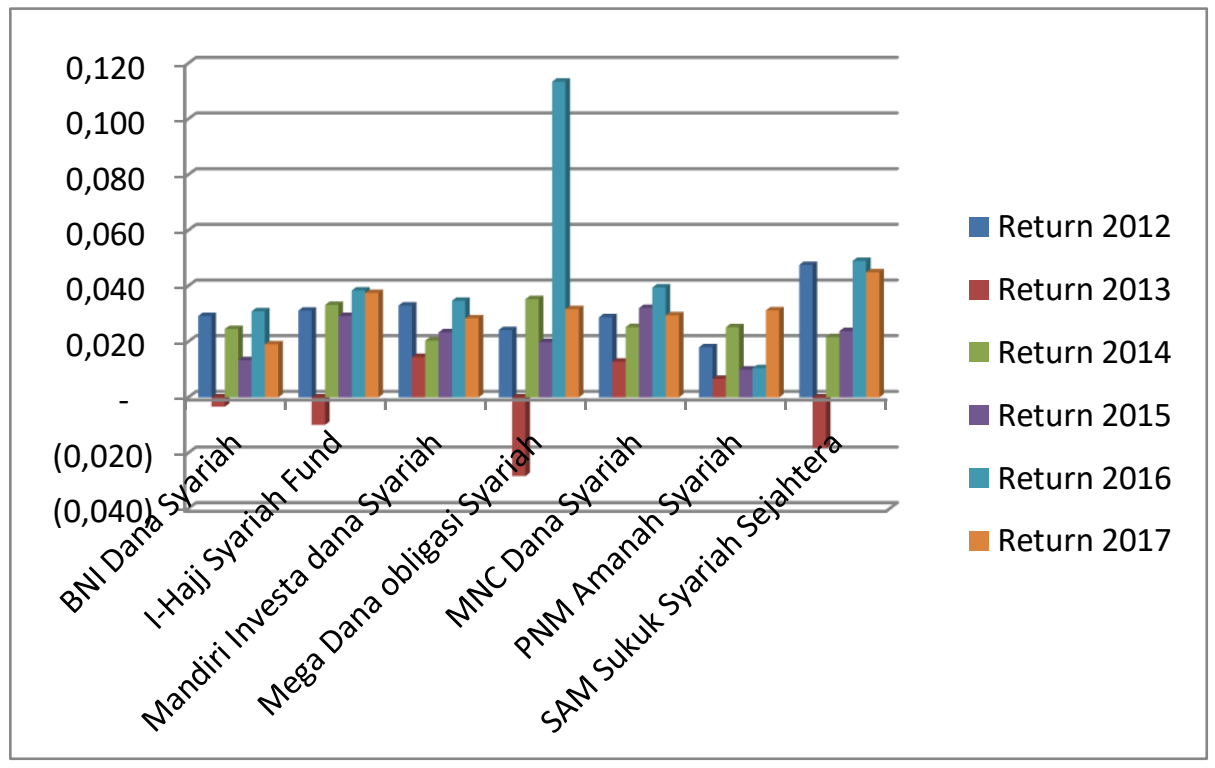

Sumber : Data Sekunder yang diolah peneliti

Dari grafik di atas terlihat bahwa dalam rentang waktu periode 2012 - 2017 daily return reksadana pendapatan tetap syariah cukup stabil dibanding reksadana saham syariah dan reksadana campuran syariah. Hanya pada periode 2013 ada 4 reksadana pendapatan tetap syariah yang mencatatkan daily retrun negatif. Pada periode 2012 seluruh reksadana pendapatan tetap syariah mencatatkan daily return positif, SAM Sukuk Syariah Sejahtera mencatatkan daily return tertinggi dibanding reksadana pendapatan tetap lainnya. Pada periode 2013 ada 4 dari 7 reksadana pendapatan tetap syariah yang mencatatkan daily retrun negatif yaitu BNI Dana Syariah, I-Hajj Syariah Fund, 
60 | Dikri Rizaldi, Azis Budi Setiawan, Muhammad Doddy AB : Analisis Kinerja Reksadana Syariah (Kategori Saham, Campuran dan Pendapatan Tetap) Periode 2012-2017

Mega Dana Obligasi Syariah dan SAM Sukuk Syariah Sejahtera. Pada periode 2014 seluruh reksadana pendapatan tetap syariah mencatatkan daily return positif, Mega Dana Obligasi Syariah mencatatkan daily return tertinggi dibanding reksadana pendapatan tetap syariah lainnya.

Pada periode 2015 seluruh reksadana pendapatan tetap syariah mencatatkan daily return positif, MNC Dana Syariah mencatatkan daily return tertinggi dibanding reksadana pendapatan tetap syariah lainnya. Pada periode 2016 seluruh reksadana pendapatan tetap syariah lainnya mencatatkan daily return positif, Mega Dana Obligasi Syariah mencatatkan daily return tertinggi dibanding reksadana pendapatan tetap syariah lainnya. Pada periode 2017 seluruh reksadana pendapatan tetap syariah mencatatkan daily return positif, SAM Sukuk Syariah Sejahtera mencatatkan daily return tertinggi dibanding reksadana pendapatan tetap lainnya.

\section{d. Kinerja Reksadana Syariah Menggunakan Metode Sharpe}

Pengukuran kinerja dengan memasukan unsur risiko terhadap 7 Reksadana Syariah Saham, 7 Reksadana Syariah Pendapatan tetap dan 9 Reksadana Syariah campuran selama periode Januari 2012 sampai dengan Desember 2017 menggunakan metode Sharpe.

Langkah dalam menghitung kinerja reksadana menggunakan metode Sharpe dengan menggunakan langkah sebagai berikut :

Keterangan :

$$
\mathrm{S}_{\mathrm{RD}}=\frac{\text { KINERJA }_{R D}-\text { KINERJA }_{R F}}{\sigma}
$$

$\mathrm{S}_{\mathrm{RD}} \quad=$ Nilai Rasio Sharpe

Kinerja $a_{\mathrm{RD}}=$ Rata-rata kinerja Reksadana subperiode tertentu

Kinerja $_{\mathrm{RF}}=$ Rata-rata kinerja investasi bebas risiko sub periode tertentu

$\sigma \quad=$ Standar deviasi reksadana untuk subperiode tertentu

\section{e. Kinerja Reksadana Syariah Saham}

Pengukuran dengan metode Sharpe didasarkan atas premium atas risiko (risk premium) yaitu perbedaan selisih antara rata- rata kinerja yang dihasilkan oleh reksadana dan rata- rata kinerja bebas risiko (risk free assets). Investasi tanpa risiko diasumsikan dengan tingkat bunga rata- rata dari sertifikat Bank Indonesia.

Reksadana Syariah Saham yang memiliki nilai Sharpe paling tinggi dan memduduki rangking pertama pada periode Januari sampai Desember 2012 adalah Trim Saham Syariah 0.06463, kemudian pada periode Januari sampai Desember 2013 adalah Cipta Equity Syariah 0.01284, kemudian pada periode Januari sampai Desember 2014 adalah PNM Ekuitas Syariah 0.13603, kemudian pada periode Januari sampai Desember 2015 adalah Manulife Syariah Sektoral Amanah -0.04413, selanjutnya pada periode Januari sampai Desember 2016 adalah Manulife Syariah sektoral Amanah 0.04660, dan 
Jurnal Ekonomi dan Perbankan Syariah

Vol. 7. No.2, Agustus 2018: 45-63, ISSN (cet): 2355-1755 | ISSN (online): 2579-

6437

| 61

terakhir pada periode Januari sampai Desember 2017 adalah Batavia Dana Saham Syariah 0.03913.

\section{f. Kinerja Reksadana Syariah Campuran}

Pengukuran kinerja Reksadana Syariah Campuran memasukan unsur risiko terhadap 9 Reksadana Syariah Campuran periode Januari 2012 sampai dengan Desember 2017 menggunakan metode Sharpe.

Reksadana Syariah pendapatan tetap yang memiliki nilai paling tinggi dan menduduki rangking pertama pada periode Januari sampai Desember 2012 adalah SAM Syariah Berimbang 0.11076, kemudian pada periode Januari sampai Desember 2013 adalah SAM Syariah Berimbang 0.02013, kemudian pada periode Januari sampai Desember 2014 adalah TRIM Syariah Berimbang 0.13049, kemudian pada periode Januari sampai Desember 2015 adalah Schorder Syariah Balance Fund -0.00026, selanjutnya pada periode Januari sampai Desember 2016 adalah AAA Amanah Syariah Fund 0.10017, dan terakhir pada periode Januari sampai Desember 2017 adalah TRIM Syariah Berimbang 0.13049.

\section{g. Kinerja Reksadana Syariah Pendapatan Tetap}

Pengukuran kinerja Reksadana Syariah Pendapatan Tetap memasukan unsur risiko terhadap 7 Reksadana Syariah Pendapatan Tetap periode Januari 2012 sampai dengan Desember 2017 menggunakan metode Sharpe.

Reksadana Syariah Pendapatan tetap yang memilik kinerja yang paling baik dan menempati rangking pertama pada periode Januari sampai Desember 2012 adalah MNC Dana Syariah 1.26905, kemudian pada periode Januari sampai Desember 2013 adalah MNC Dana Syariah 0.11905, kemudian pada periode Januari sampai Desember 2014 adalah MNC Dana Syariah 0.75011, kemudian pada periode Januari sampai Desember 2015 adalah I-Hajj Syariah Fund 0.30308, selanjutnya pada periode Januari sampai Desember 2016 adalah MNC Dana Syariah 0.81488, dan terakhir pada periode Januari sampai dengan Desember 2017 adalah MNC Dana Syariah 1.34044.

\section{PENUTUP}

Berdasarkan hasil analisis data dan pembahasan hasil penelitian yang dilakukan untuk mengetahui perbandingan kinerja Reksadana Syariah Saham, Campuran dan Pendapatan Tetap dengan menggunakan metode Sharpe, maka dapat ditarik kesimpulan bahwa : Kinerja Reksadana Syariah Saham yang memiliki kinerja paling baik yang direkomendasikan penulis dalam periode 2012 sampai 2017 adalah TRIM Saham Syariah, Cipta Equity Syariah, PNM Ekuitas Syariah, Manulife Sektoral Syariah Amanah dan Batavia Dana Saham Syariah dibanding kinerja reksadana saham syariah lainnya. Untuk kinerja 
62 | Dikri Rizaldi, Azis Budi Setiawan, Muhammad Doddy AB : Analisis Kinerja Reksadana Syariah (Kategori Saham, Campuran dan Pendapatan Tetap) Periode 2012-2017

reksadana syariah Campuran yang memiliki kinerja paling baik periode 2012 sampai 2017 adalah SAM Syariah Berimbang, TRIM Syariah Berimbang, Schorder Syariah Balance Fund, AAA Amanah Syariah Fund serta TRIM Syariah Berimbang. Dan kinerja reksadana syariah Pendapatan tetap yang memiliki kinerja paling baik tahun 2012 sampai 2017 adalah MNC Dana Syariah Sejahtera serta I-Hajj Syariah Fund dibanding dengan kinerja reksadana pendapatan tetap lainnya.

\section{DAFTAR PUSTAKA}

Cahyono, J. E. (2001). Cara jitu meraih untung dari reksadana. jakarta : Elex Media komputindo.

Darmadji, T., \& Fachruddin, h. (2001). Pasar Modal Indonesia : Pendekatan tanya jawab. Jakarta : Salemba Empat.

Darmadji, T., \& Fachrudin, H. M. (2008). Pasar Modal di Indonesia Pendekatan Tanya Jawab. jakarta: Salemba Empat.

Darmadji, T., \& Fakhrudin, H. M. (2006). Pasar Modal di Indonesia. Jakarta: Salemba Empat.

Fabozzi, F. J. (1999). Pasar dan Lembaga Keuangan. Jakarta: Salemba empat.

Fahmi, I. (2012). Manajemen investasi. Jakarta: Salemba empat.

Fahmi, I. (2012). Manajemen Investasi. Jakarta: Salemba Empat.

Fahmi, i. (2012). pengantar pasar modal. Bandung: Alfabeta.

Fardiansyah, T. (2002). Kiat dan Startegi menjadi Investor piawai. Jakarta: Gramedia.

Ghazali, A. (2004). Mengenal dan Memilih Produk Investasi Syariah . Jakarta: Elex Media Komputindo .

Hamid, A. (2009). Pasar Modal Syariah. Jakarta: Lembaga Penelitian UIN Jakarta.

Hartono, J. (2013). Teori Portofolio dan Analisis Investasi. Yogyakarta: BPFE UGM.

Huda, N., \& Nasution, M. E. (2007). Investasi pada Pasar Modal Syariah. Jakarta: Kencana.

Huda, N., \& Nasution, M. E. (2014). Investasi Pada Pasar Modal Syariah Edisi Revisi. Jakarta: Kencana Prenada Media group.

Husnan. (2003). Dasar- Dasar Teori Portofolio dan Analisis Sekuritas. Yogyakarta: UPP AMP YPKN.

Manan, A. (2009). Aspek Hukum dalam Penyelenggaraan Investasi di Pasar Modal Syariah. Jakarta: Kencana Media Prananda Group.

Manurung, A. H. (2003). Reksadana. Jakarta: Adler Manurung Press.

Murtanto, N. (2012). Metode Penelitian kuantitaitf Analisis isi dan analisis data sekunder. Jakarta: Rajawali pers.

Nurjannah. (2015). Mengenal Manajer Investasi dan Reksa dana. Bandung: Zavara.

Pratomo, E. P. (2004). Berwisata ke dunia Reksa Dana. Jakarta: Gramedia Media Utama.

Pratomo, E. P., \& Nugraha, U. (2005). Reksadana Solusi Perencanaan Investasi di Era Modern. Jakarta: PT. Gramedia Pustaka Umum. 
Jurnal Ekonomi dan Perbankan Syariah

Vol. 7. No.2, Agustus 2018: 45-63, ISSN (cet): 2355-1755 | ISSN (online): 2579-

6437

| 63

Prayitno, E. B., \& Pangalila, R. (2008). Menjadi Kaya Melalui Reksa Dana. Jakarta: Elex Media Komputindo.

Priyo, E., \& Nugaraha, U. (2002). Reksa Dana Solusi Perencanaan Investasi di Era Modern. Jakarta: Gramedia Pustaka Utama.

Priyo, E., \& Nugraha, U. (2002). Reksa Dana solusi investasi perencanaan investasi di era modern. Jakarta: Gramedia Pustaka Utama.

Rohmatusya'diyah, A. (2011). hukum investasi dan pasar modal. jakarta: sinar grafika offset.

Rudiyanto. (2015). Sukses Finansial dengan Reksa Dana. Jakarta: PT. Elex Media Komputindo.

Samsul, M. (2015). Pasar Modal \& Manajemen Portofolio. Jakarta: Erlangga.

Situmorang, P. (2010). Langkah awal berinvestasi reksa dana. Jakarta: Transmedia Pustaka.

Soewadji, J. (2012). Pengantar metodologi penelitian. jakarta: Mitra Wacana Media.

Sudarsono, H. (2007). Bank dan Lembaga keuangan Syariah : Deskripsi dan ilustrasi. yogyakarta: Ekanusia.

Suharyadi, \& Purwanto. (2007). Statistika untuk ekonomi dan keuangan modern. Jakarta: Salemba Empat.

Suketi, \& Wahyudi. (2011). Analisis Perbandingan Return Reksa Dana dengan Return Benchmark berdasarkan Metode Sharpe, Treynor, Jensen dan M2 studi pada Reksa dana Saham, Penadapatan Tetap dan Campuran periode tahun 2005-2009). Jurnal universitas Diponegoro, 1-33.

Sunariyah. (2005). Pengantar pengetahuan pasar modal edisi kelima. yogyakarta: Sekolah tinggi Ilmu Manajemen YKPN.

Supranto, j. (2000). Statistik teori dan aplikasi. Jakarta: Erlangga.

Susilatri, Ratnawati, \& Khairani. (2014). Reksa Dana Syariah dan Reksa Dana Konvensional. Fakultas Ekonomi Universitas Riau, 11-29.

Trianto. (2010). Pengantar Penelitain Pendidikan bagi pengembangan profesi pendidikan tenaga kependidikan. Jakarta : Kencana.

Yuliana, I. (2010). Investasi Produk Keuangan Syariah. Malang: UIN Maliki Press. 